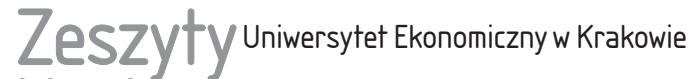 Naukowe
}

\section{Ekonomiczne uwarunkowania zachowań konsumpcyjnych gospodarstw domowych w Polsce w latach 2006-2015}

\section{Streszczenie}

Celem artykułu jest określenie czynników, które determinują zachowania konsumpcyjne gospodarstw domowych, ze szczególnym uwzględnieniem tych o charakterze ekonomicznym. Biorąc pod uwagę specyfikę warunków, w jakich funkcjonują współczesne gospodarstwa domowe, w opracowaniu podjęto próbę określenia tego typu czynników działających nie tylko w skali mikro- czy makroekonomicznej, ale również w skali globalnej. W artykule przeprowadzono analizę determinant zachowań konsumpcyjnych polskich gospodarstw domowych od 2006 r., czyli w okresie, kiedy gospodarstwa te zaczęły stopniowo odczuwać skutki wstąpienia do Unii Europejskiej. Według wstępnych wyników badań na zmiany konsumpcji polskich gospodarstw domowych w badanym okresie wpływała nie tylko zmiana ich sytuacji materialnej w postaci wzrostu dochodów czy wartości posiadanych aktywów, ale także bieżąca i oczekiwana koniunktura gospodarcza w kraju i na świecie.

Słowa kluczowe: gospodarstwo domowe, konsumpcja, globalizacja, koniunktura konsumencka.

Klasyfikacja JEL: D11.

Dominika Choroś-Mrozowska, Uniwersytet Ekonomiczny w Krakowie, Wydział Finansów i Prawa, Katedra Ekonomii, ul. Rakowicka 27,31-510 Kraków, e-mail: mrozowsd@uek.krakow.pl David Clowes, Uniwersytet Ekonomiczny w Krakowie, Wydział Finansów i Prawa, Katedra Ekonomii, ul. Rakowicka 27, 31-510 Kraków, e-mail: clowesd@uek.krakow.pl 


\section{Wprowadzenie}

Jak pisze A. Grotowska-Leder (2011, s. 180): „Gospodarczym aktorem jest przede wszystkim pojedynczy człowiek (...). W procesie organizowania środków na zaspokajanie niezbędnych potrzeb i ich dystrybuowania podstawowa rola przypada gospodarstwu domowemu". Według twórcy ekonomicznej teorii zachowań ludzkich, G. Beckera (1990), gospodarstwo domowe znacząco różni się od innych podmiotów gospodarczych, gdyż jego głównym celem nie jest maksymalizacja zysku, ale właśnie jak najlepsze zaspokojenie potrzeb. Realizacja tego celu jest zadaniem trudnym ze względu na złożoność procesu zaspokajania potrzeb, na który wpływają zarówno cele i aspiracje życiowe członków gospodarstwa domowego, postawy ludzkie, zakupy dóbr i usług konsumpcyjnych, potrzeby, zasoby pieniężne i rzeczowe oraz wielkość spożycia realnego (Zalega 2011, s. 470). Wynika to jednak przede wszystkim z faktu, że owo dążenie do jak najlepszego zaspokojenia potrzeb, motywujące gospodarstwo domowe do działania, odbywa się z założenia w warunkach relatywnego ograniczenia dostępnych zasobów.

W przypadku polskich gospodarstw domowych, które od prawie trzech dekad muszą mierzyć się z głębokimi zmianami zachodzącymi zarówno w obszarze gospodarczym, politycznym, jak i społecznym, realizacja ich podstawowych funkcji wydaje się zadaniem tym bardziej złożonym. Warto podkreślić, że rozwojowi gospodarki rynkowej, jaki następuje w Polsce od początku lat 90., towarzyszą procesy o znacznie szerszym zasięgu. Dotyczy to przede wszystkim rozwoju nowoczesnych technologii oraz globalizacji, która determinuje aktualne wzorce konsumpcji gospodarstw domowych na całym świecie. Oznacza to często coraz większe potrzeby Polaków, które ulegają stopniowej unifikacji w skali ponadnarodowej, upodabniając się do potrzeb społeczeństw głównie z krajów wysoko rozwiniętych. Z drugiej strony należy zaznaczyć, że polskie gospodarstwa domowe, mające coraz większe potrzeby konsumpcyjne, są zmuszone realizować je przy znacznie niższym średnim poziomie dochodów.

W związku z tym główny cel niniejszego opracowania stanowi określenie czynników, które determinują zachowania konsumpcyjne gospodarstw domowych, ze szczególnym uwzględnieniem tych o charakterze ekonomicznym. Biorąc pod uwagę specyfikę warunków, w jakich funkcjonują współczesne gospodarstwa domowe, w artykule podjęto próbę określenia tego typu czynników działających w skali nie tylko mikro- czy makroekonomicznej, ale również globalnej. W ostatniej części opracowania przeprowadzono analizę determinant zachowań konsumpcyjnych polskich gospodarstw domowych od 2006 r., czyli w okresie, kiedy gospodarstwa te zaczęły stopniowo odczuwać skutki wstąpienia do Unii Europejskiej. 


\section{Mikroekonomiczne determinanty konsumpcji gospodarstw domowych}

Jedną z podstawowych aktywności gospodarstwa domowego stanowi konsumpcja będąca złożonym procesem działań i zachowań zmierzającym do wyboru oraz pozyskania środków konsumpcji, jak i obchodzenia się z nimi oraz ich spożywania (Szczepański 1981, s. 132-136). To, w jakim stopniu gospodarstwa domowe zaspokoją swoje potrzeby w wyniku korzystania zarówno z nabytych dóbr i usług, jak i z tych udostępnionych im przez państwo, determinuje ich poziom życia (Luszniewicz 1972, s. 28-32).

To, jakie potrzeby występują oraz jakie są sposoby ich zaspokojenia w danym gospodarstwie domowym, zależy od wielu różnorodnych czynników, w tym tych o naturze ekonomicznej. W tej części opracowania skoncentrowano się na mikroekonomicznych determinantach konsumpcji. Zalicza się do nich m.in. sytuację ekonomiczną gospodarstwa domowego, na którą składają się głównie posiadane zasoby majątkowe, zobowiązania wobec innych podmiotów oraz dochody. Ludzi, w zależności od tego, jaka jest ich sytuacja materialna, charakteryzuje różny poziom i struktura konsumpcji. Z reguły w zamożnych gospodarstwach domowych wydaje się więcej (w wartościach absolutnych) na konsumpcję wszystkich rodzajów dóbr, przy czym udział dóbr podstawowych w ich całkowitych wydatkach będzie niższy niż w gospodarstwach mniej zamożnych.

Zasoby majątkowe gospodarstwa domowego mogą służyć do bezpośredniego lub pośredniego zaspokojenia potrzeb konsumpcyjnych jego członków. Wpływ bezpośredni realizowany jest przez ich użyteczność, a odnosi się przede wszystkim do różnego typu dóbr konsumpcyjnych. Wpływ pośredni dotyczy głównie dóbr kapitałowych, które mogą zostać spieniężone czy wydzierżawione, a środki dzięki temu pozyskane przeznaczone na bieżącą konsumpcję.

Kolejnym czynnikiem determinującym poziom życia, a tym samym również wzorce konsumpcji, są dochody. Analizując zachowania gospodarstw domowych w kontekście wysokości uzyskiwanych przez nie dochodów, warto wyodrębnić gospodarstwa domowe wysokodochodowe. W tych gospodarstwach decydujący udział w dochodach mają dochody z pracy, które są wyższe w stosunku do tych uzyskiwanych przez pozostałe gospodarstwa domowe. Gospodarstwa te wydają więcej na dobra tzw. trzeciego rzędu, do których zalicza się dobra informacyjne, zajęcia związane z kulturą i spędzaniem wolnego czasu, edukację oraz sztukę (Douglas i Isherwood 1996, Palska 2000, Zalega 2011). Co ważne, to, jak dochody oddziałują na zachowania ekonomiczne gospodarstw domowych, zależy od tego, czy mamy do czynienia z tzw. dochodem stałym (permanentnym), uzyskiwanym przez gospodarstwo domowe regularnie, czy tym doraźnym, nieregularnym. Według badań empirycznych ich wpływ na wydatki konsumpcyjne gospodarstw 
domowych jest w obu tych przypadkach odmienny. To, jak gospodarstwa domowe zachowują się w sferze konsumpcji, zależy również od tego, jak ich dochody rozłożone są w czasie - jest to związane z tzw. hipotezą cyklu życia. Zgodnie z tą teorią podmioty przeznaczają na konsumpcję stały ułamek bieżącej wartości swojego dochodu uzyskanego w ciągu całego życia.

Sytuację materialną gospodarstwa domowego determinuje więc zarówno posiadany majątek, jak i poziom bieżących dochodów ${ }^{1}$ (Deaton 1974), a wpływ tych dwóch elementów na zachowania ekonomiczne gospodarstw domowych może być nie tylko substytucyjny, ale także komplementarny, kiedy to niskie dochody bieżące kompensowane są nagromadzonym wcześniej majątkiem² ${ }^{2}$ To, w jakim stopniu zmieniają się wydatki gospodarstwa domowego (a tym samym jego konsumpcja) w reakcji na zmiany realnej wartości majątku, nazwano efektem majątkowym.

Poza sytuacją ekonomiczną gospodarstwa domowe kierują się w swych decyzjach konsumpcyjnych informacjami płynącymi z rynku dóbr i usług. Jedną z głównych determinant wyborów dokonywanych przez gospodarstwo domowe dotyczących konsumpcji jest poziom cen (Hodoly 1971). Zgodnie z prawem popytu wzrostowi cen towarzyszy spadek zapotrzebowania i przeciwnie - spadkowi cen towarzyszy wzrost wielkości popytu. Jest to związane z wpływem zmian cen na dochody realne konsumentów, które mogą się zwiększać lub zmniejszać w zależności od tego, czy tempo wzrostu cen jest niższe, czy wyższe od tempa wzrostu dochodów nominalnych ${ }^{3}$. Na decyzje konsumpcyjne gospodarstw domowych wpływają również oczekiwania co do przyszłych zmian cen, czyli tzw. oczekiwania inflacyjne. Procesy inflacyjne stanowią znaczne utrudnienie racjonalnego zachowania się podmiotów na rynku towarów i usług. W sytuacji wysokiej inflacji gospodarstwa domowe starają się uciec od pieniądza w obawie przed utratą jego realnej wartości, lokując swój majątek zazwyczaj w różnego typu aktywach trwałych.

Oprócz inflacji na konsumpcję gospodarstw domowych wpływa także - stanowiąca jej przeciwieństwo - deflacja. Mimo że deflacja może oznaczać zwiększenie możliwości nabywczych konsumentów, zazwyczaj jest zjawiskiem niekorzystnym. $Z$ reguły towarzyszy jej wzrost bezrobocia, co prowadzi do pogorszenia

${ }^{1}$ Ważną rolę w decyzjach konsumpcyjnych gospodarstw domowych pełnią również oczekiwane przyszłe dochody gospodarstw domowych.

${ }^{2} \mathrm{~W}$ przypadku gospodarstw domowych nieposiadających majątku ich konsumpcja - poza bieżącym dochodem - zależy także od tego, czy korzystają one z pożyczek lub kredytów konsumpcyjnych.

${ }^{3}$ Należy zaznaczyć, że zmiana ceny danego dobra wpływa nie tylko na zapotrzebowanie na to dobro, ale również na popyt na dobra wobec niego substytucyjne i/lub komplementarne. Szerzej na ten temat zob. (Bywalec 2012, s. 36-37). 
się sytuacji materialnej gospodarstw domowych, a w efekcie również do spadku konsumpcji ${ }^{4}$.

Wpływ na zachowania gospodarstw domowych w sferze konsumpcji ma także podaż dóbr i usług, oznaczająca zarówno ich ilość, asortyment, jak i jakość oraz walory techniczno-użytkowe. Bardzo istotne są również sposoby dystrybucji towarów związane z poziomem i organizacją zaopatrzenia rynku. Obecnie znacznie skraca się cykl życia produktów, na rynek wchodzą nowocześniejsze wersje danego towaru, a towarzyszy temu aktywna promocja, co znacznie przyspiesza jego zużycie ekonomiczne. Prowadzi to do międzyokresowej substytucji konsumpcji, czyli zastępowania dóbr już użytkowanych nowszym, bardziej nowoczesnym asortymentem. Konsumenci decydują o wstrzymaniu się z zakupem, czekając na następną wersję danego produktu, lub wręcz przeciwnie, gdy na rynku pojawia się nowszy model, wymieniają na niego posiadane już urządzenie (dotyczy to głównie sprzętu wysokiej technologii).

Współczesnym podmiotom gospodarczym coraz trudniej jest podjąć decyzję co do zakupu. Jest to efekt ciągłych zmian zachodzących na rynkach charakteryzujących się zazwyczaj znaczną obfitością towarów o zróżnicowanych cechach, funkcjach oraz cenach. Problem wyboru potęgują działania promocyjne przedsiębiorstw, których celem nie jest rzetelna informacja o produkcie, a nakłonienie konsumenta do zakupu. W tych warunkach wybory gospodarstw domowych często nie są, z punktu widzenia ekonomii, racjonalne.

\section{Czynniki makroekonomiczne a konsumpcja gospodarstw domowych}

To, jakie decyzje gospodarstwa domowe podejmują w sferze konsumpcji, zależy nie tylko od ich sytuacji materialnej czy warunków panujących na rynkach dóbr i usług, ale także od polityki rządu czy kondycji ekonomicznej kraju.

Przez narzędzia, które państwo wykorzystuje do stymulowania wzrostu gospodarczego oraz poprawy warunków życia obywateli w ramach polityki gospodarczej i społecznej, oddziałuje ono również, na poziom i strukturę ich konsumpcji. Dotyczy to m.in. polityki fiskalnej, na którą składają się podatki i wydatki państwa. Do jej celów należą ograniczenie nadmiernego zróżnicowania dochodów czy walka z bezrobociem (https://www.nbpportal.pl, data dostępu: 27.09.2016). Przez m.in. stopy podatkowe, progi podatkowe, ulgi, zwolnienia podatkowe czy wydatki publiczne wpływa ona na dochody rozporządzalne obywateli, a także ich konsumpcję. Przez kształtowanie i egzekucję podatków, szczególnie

${ }^{4}$ Deflacja może prowadzić do pojawienia się tzw. efektu Pigou. Szerzej na ten temat zob. (Polityka makroekonomiczna... 2011). 
podatków bezpośrednich, państwo zmniejsza dochody gospodarstw domowych (w przypadku podatku PIT) lub wartość posiadanych przez nie aktywów (podatek majątkowy). Konsumpcja może być również modyfikowana przez mechanizm podatków pośrednich, takich jak VAT czy akcyza. Te ostatnie podnoszą finalną cenę towaru ${ }^{5}$, co z jednej strony wpływa na decyzję gospodarstwa dotyczącą jego nabycia, z drugiej - jeżeli zdecyduje się ono na zakup, szczególnie w przypadku dobra obłożonego wysokim podatkiem - ogranicza jego środki finansowe, które mogłyby być przeznaczone na inne towary lub usługi ${ }^{6}$. Zmiany w polityce fiskalnej mogą też przez inne mechanizmy wpływać na konsumpcję gospodarstw domowych. Obniżenie podatków powoduje m.in. zwiększenie opłacalności działalności gospodarczej, co przez mechanizm zwiększenia popytu na pracę wypływa na wzrost dochodów gospodarstw domowych, a tym samym podniesienie ich siły nabywczej. Co ważne, nie tylko aktualna polityka państwa determinuje zachowania gospodarstw domowych w sferze konsumpcji, ale także ich oczekiwania co do przyszłych działań rządu?

Wpływ państwa na wydatki gospodarstw domowych jest szczególnie odczuwalny w zakresie polityki dochodowej, cenowej oraz wydatków publicznych. Poza tym, że państwo bezpośrednio ustala wynagrodzenia w sektorze publicznym, wpływa również na poziom świadczeń socjalnych, np. przez ustalenie ich minimalnego poziomu czy sposobów indeksacji. Konkretnym przykładem ingerencji państwa w ramach polityki dochodowej, która wpływa na cały system płacowy, jest ustalanie płacy minimalnej czy kwoty wolnej od podatku (Bywalec 2010). Istotny wpływ na poziom i strukturę konsumpcji gospodarstw domowych mają również wydatki państwa. To, że rząd zapewnia bezpłatny (lub częściowo odpłatny) dostęp do różnego typu dóbr, takich jak edukacja, ochrona zdrowia, transport, kultura itp., oznacza, że gospodarstwa domowe mają dodatkowe środki na zaspokojenie innych potrzeb. Wysokie wydatki publiczne muszą mieć jednak źródło finansowania, takie jak m.in. podatki bezpośrednie płacone przez gospodarstwa domowe (głównie bardziej zamożne), którym w ten sposób ogranicza się ich siłę nabywczą.

Duży wpływ na to, jak gospodarstwa domowe zachowują się w sferze konsumpcji, ma polityka pieniężna państwa. Bank centralny odpowiedzialny ze jej realizację może np. próbować ożywić gospodarkę, zwiększając podaż pieniądza.

5 Państwo może też bezpośrednio ustalać ceny urzędowe na wybrane towary (dotyczy to np. cen usług medycznych czy mediów). Spotykane są również przypadki określania ceny minimalnej lub maksymalnej w celu ochrony danej grupy podmiotów.

${ }^{6}$ Podatki pośrednie mogą wywołać efekt dochodowy, a także komplementarny i substytucyjny. Siła tych efektów uzależniona jest od rodzaju dobra, stawki podatku oraz zamożności gospodarstwa domowego.

7 Szerzej na temat wpływu państwa (czynników makroekonomicznych i makrospołecznych) zob. (Bywalec 2012, s. 43-47). 
W tych warunkach niższe oprocentowanie kredytów i pożyczek, a tym samym ich większa dostępność, aktywizuje konsumpcję. Wzrost konsumpcji jest też konsekwencją zwiększonych inwestycji realizowanych dzięki tanim kredytom, które oznaczają wzrost produkcji, zatrudnienia oraz dochodów ludności. Inne konsekwencje ma restrykcyjna polityka monetarna. Działania państwa w sferze polityki monetarnej mogą mieć swoje konsekwencje w postaci inflacji (deflacji), co również przekłada się na zachowania konsumpcyjne gospodarstw domowych, których mechanizm przedstawiony został w poprzedniej części opracowania.

Nie tylko jednak polityka państwa, ale także jego kondycja, w sensie poziomu i tempa wzrostu gospodarczego czy szerzej rozumianego rozwoju gospodarczego, wpływa na decyzje podmiotów w sferze konsumpcji. Obywatele krajów wysoko rozwiniętych cieszą się z reguły wyższym poziomem życia niż obywatele krajów rozwijających się. Im wyższa jest natomiast dynamika wzrostu gospodarczego, tym szybciej rośnie prywatna konsumpcja, a tym samym poprawia się również poziom życia obywateli.

Poza wielkością czy tempem wzrostu PKB na konsumpcję gospodarstw domowych istotny wpływ ma także jego struktura. Relacja między konsumpcją prywatną a inwestycjami istotnie determinuje przyszłą konsumpcję. W przypadku gdy znaczna część PKB jest „konsumowana”, a nie przeznaczana na inwestycje, gospodarka zbyt wolno zwiększa swoje możliwości produkcyjne, co ma negatywny wpływ na rynek pracy, dochody ludności oraz rynek dóbr i usług. Gospodarstwa domowe, podejmując swoje decyzje konsumpcyjne, kierują się więc nie tylko aktualnym stanem gospodarki, ale tym, jak zmienia się sytuacja ekonomiczna w czasie. Konsumpcja zazwyczaj wzrasta, gdy gospodarstwa zauważają poprawę aktualnej sytuacji gospodarczej w kraju, a maleje w przypadku tendencji odwrotnej.

Zależność między konsumpcją a koniunkturą gospodarczą kraju jest szczególnie widoczna w okresie kryzysu. Według T. Zalegi (2013) na postrzeganie i ocenę kryzysu przez gospodarstwa domowe w dużym stopniu wpływają ich wcześniejsze doświadczenia, poziom życia czy poczucie bezpieczeństwa ekonomicznego. Kryzys wpływa na zmianę zarówno niektórych zwyczajów gospodarstw domowych związanych z konsumpcją (np. preferowanych form płatności: gotówka zamiast karty, czy ilości kupowanych dóbr i usług), jak i ich nastawienia do różnych trendów konsumpcyjnych, takich jak np. konsumpcja zrównoważona czy ekologiczna. Wśród konsekwencji kryzysu wyróżnić można dwa podstawowe typy zachowań konsumpcyjnych gospodarstw domowych. Pierwsze, tzw. zachowania kryzysowe, przejawiają się ograniczeniem bieżących wydatków konsumpcyjnych oraz stopnia zaspokojenia potrzeb wyższego rzędu. Drugi typ, tzw. zachowania postkryzysowe, oznaczają kontynuację zachowań kryzysowych lub zmianę stylu życia w okresie po kryzysie. Co istotne, w czasie kryzysu gospodarczego można także zaobserwować zmiany w niektórych wzorcach konsumpcji (nastę- 
puje np. osłabienie serwicyzacji czy konsumpcjonizmu, umacnia się natomiast świadoma konsumpcja, smart shopping czy domocentryzm) (Rachocka 2003, Nowak 2012). Gospodarstwa domowe zaczynają coraz częściej także korzystać z samozaopatrzenia. Jak wynika z badań, wpływ kryzysu na konsumpcję gospodarstw domowych nie ogranicza się jednak tylko do ograniczenia ich ilościowego spożycia, często wpływa też na jakość konsumpcji ${ }^{8}$. Po zakończeniu kryzysu ubogie gospodarstwa, wcześniej zmuszone do ograniczenia konsumpcji, mogą powrócić do dawnych zwyczajów. Natomiast gospodarstwa domowe, które przed kryzysem mało racjonalnie zarządzały budżetem, w jego trakcie zmuszone są zazwyczaj do rewizji swoich zachowań w sferze konsumpcji. Zakończenie kryzysu nie zawsze jednak oznacza w tym wypadku powrót do tzw. konsumeryzmu.

\section{Globalizacja a zachowania konsumpcyjne gospodarstw domowych}

Jednym z najważniejszych procesów mających wpływ na współczesną światową gospodarkę, a tym samym poszczególne gospodarki narodowe, jest globalizacja. Oznacza ona przeobrażenia o charakterze głównie gospodarczym, które polegają m.in. na liberalizacji przepływów handlowych, ograniczeniu roli państwa w gospodarce, zwiększeniu znaczenia korporacji transnarodowych czy internacjonalizacji kapitału. Wzmożone przepływy towarów, usług, pracy i kapitału, stanowiące przejawy procesów globalizacyjnych w dużej mierze determinują stan współczesnych gospodarek, co ma swoje przełożenie na współczesne wzorce konsumpcji. Z tego powodu w literaturze przedmiotu pojawia się pojęcie globalizacji konsumpcji, która oznacza rozprzestrzenianie się identycznych lub bardzo podobnych wzorców konsumpcji, czyli tzw. homogenizacja konsumpcji, w skali ponadnarodowej, jak i tworzeniu się tzw. globalnej kultury konsumpcyjnej. Wzorce te najczęściej utożsamiane są z jednym krajem - USA, stąd też proces ten zyskał również miano amerykanizacji, makdonaldyzacji lub westernizacji (Bywalec i Rudnicki 2002, s. 136-137). Przejawia się to w większej dostępności towarów zagranicznych, co oznacza większą różnorodność towarów na krajowym rynku, a tym samym duże możliwości zaspokojenia potrzeb konsumpcyjnych gospodarstw domowych. Zwiększona konkurencja na krajowym rynku wpływa też na zachowania rodzimych producentów, czego częstym efektem jest obniżenie cen towarów i usług. Warto również zaznaczyć, że wzmożone przepływy, szczególnie towarów, usług, kapitału i ludzi, przyczyniają się do dyfuzji informacji, idei oraz kultury, co ma ogromny

${ }^{8}$ Głównym miernikiem reakcji gospodarstw domowych na kryzys gospodarczy jest spadek zaufania konsumpcyjnego. Szerzej na ten temat zob. (Bohlen, Carlotti i Mihas 2010, Desvaux i in. 2009, Graham 2010, Hermann 2009). 
wpływ na zmiany we wzorcach konsumpcji. Prowadzi to do powstania transnarodowych segmentów rynku, które obejmują jednorodne grupy konsumentów, w skali ponadnarodowej lub nawet globalnej ${ }^{9}$ (Drabik 2011, s. 580).

Globalizacja niesie ze sobą rewolucję technologiczną, a wynalazki takie jak internet czy telefon komórkowy, będące konsekwencją tej rewolucji, kształtują wzorce zachowań ich użytkowników, czyli gospodarstw domowych w gospodarce globalnej ${ }^{10}$. Jednocześnie dostęp do nowoczesnych technologii wpływa na wzrost wydajności pracy, co przyczynia się do podniesienia dochodów gospodarstw domowych, a tym samym również do wzrostu ich konsumpcji.

Rozprzestrzenianie się globalnych wzorców konsumpcyjnych w większym stopniu dotyka kraje rozwinięte, gdyż to one są ze sobą mocniej połączone. Obecnie można zaobserwować, że trendy w zachowaniach konsumentów w bardziej rozwiniętej części świata są silnie powiązane z postępującą cyfryzacją, niedostatkiem czasu oraz dbałością o zdrowie.

Poza bezpośrednim wpływem globalizacji na zmiany wzorców konsumpcyjnych w skali świata ma ona również pośredni wpływ na gospodarstwa domowe z różnych krajów. Ze względu na coraz ściślejsze powiązania gospodarek w skali ponadnarodowej państwa odczuwają skutki pewnych procesów, które mają coraz większy, często globalny zasięg. Dotyczy to zjawisk zarówno pozytywnych, jak i negatywnych w postaci wzrostów lub spadków globalnej koniunktury.

\section{Zachowania konsumpcyjne polskich gospodarstw domowych w świetle wybranych wyników badań}

Analizując wpływ czynników ekonomicznych na zachowania konsumpcyjne gospodarstw domowych, w pierwszej kolejności skoncentrowano się na analizie zależności między wydatkami a dochodem rozporządzalnym gospodarstw domowych. Jest to szczególnie istotne, gdyż czynniki te stanowią podstawę oceny sytuacji bytowej gospodarstw domowych. Według T. Zalegi (2008a, s. 207) to właśnie wydatki, obrazując przywiązanie do określonych wzorców spożycia, są swego rodzaju fotografią zachowań konsumpcyjnych w skali makroekonomicznej. Analiza objęła lata 2006-2015, czyli okres, w którym gospodarstwa domowe

${ }^{9}$ Oznacza to, że grupa konsumentów wyodrębniona w jednym kraju (regionie) odznacza się podobnymi właściwościami jak odpowiedni segment w innym kraju (regionie). W przypadku segmentu globalnego są to odbiorcy oczekujący na taki sam (globalny) produkt na całym świecie (Drabik 2011, s. 580).

${ }^{10}$ Należy zaznaczyć, że są regiony i kraje bardziej i mniej podatne na globalizację konsumpcji. Dotyczy to również społeczeństwa (szczególnie społeczeństwa Zachodu), które według Z. Baumana (2000, s. 6-9) jest bardzo spolaryzowane. Zdaniem tego autora istnieje „zglobalizowana” (głównie materialnie) mniejszość i „zglokalizowana” większość. 
zaczęły stopniowo coraz mocniej odczuwać skutki przystąpienia Polski do UE. Jest to także czas, gdy - mimo pewnych perturbacji związanych z okresowym obniżeniem tempa wzrostu PKB oraz z efektami światowego kryzysu finansowego - nastąpiła stabilizacja przyjętych rozwiązań społeczno-ekonomicznych, które wprowadzano od początku lat 90. (Grotowska-Leder 2011, s. 186).

Według danych GUS w latach 2006-2015 sytuacja materialna polskich gospodarstw domowych systematycznie się poprawiała, o czym świadczy wzrost dochodu rozporządzalnego z 835 zł na osobę do 1386 zł (średnia roczna stopa wzrostu szacowana jest na ponad 6\%). W badanym okresie można również zaobserwować zwiększenie nadwyżki dochodów rozporządzalnych nad wydatkami z 90 zł do 295 zł, której średnioroczna stopa wzrostu wyniosła aż 22\% (Badania budżetów... 2016, s. 41). Tak wysokie tempo wzrostu stwarza też możliwość zwiększania oszczędności gospodarstw domowych na poczet przyszłej konsumpcji. W latach 2006-2015 wysokiej stopie wzrostu dochodów rozporządzalnych towarzyszył również intensywny wzrost przeciętnych miesięcznych wydatków na osobę z 745 zł do 1091 zł. Średnioroczne tempo wzrostu dochodów rozporządzalnych w tym okresie było jednak wyższe od tempa wzrostu wydatków. W konsekwencji nastąpił spadek udziału wydatków w średnich rocznych dochodach rozporządzalnych gospodarstw domowych z 89,2\% (2006 r.) do 78,7\% (2015 r.), czyli o 10,5 p.p.

Jedną z kluczowych determinant wskazujących na jakość oraz poziom zaspokojenia potrzeb stanowi wielkość i struktura wydatków konsumpcyjnych (Zalega 2008b, s. 762). W badanym okresie gospodarstwa domowe większość swoich dochodów rozporządzalnych przeznaczały na tego typu dobra, na które w 2006 r. wydawały przeciętnie prawie 713 zł na osobę, co stanowiło ponad 85\% ich dochodu rozporządzalnego i ok. 96\% wydatków ogółem. W 2015 r. kwota ta wzrosła (w stosunku do 2006 r.) o ok. $330 \mathrm{zł}$ (wzrost o 46\%) do 1043 zł na osobę (75\% dochodu rozporządzalnego i 95\% wydatków ogółem), co oznacza średnioroczne tempo wzrostu wynoszące ok. 4,7\% (Badania budżetów... 2016, s. 47).

$\mathrm{W}$ analizowanym okresie, mimo spadku udziału całkowitych wydatków w dochodach rozporządzalnych polskich gospodarstw domowych, nie stwierdzono jednak istotnej obniżki udziału wydatków na dobra podstawowe, takie jak utrzymanie mieszkania lub domu oraz nośniki energii. Prawidłowość ta w mniejszym stopniu dotyczy wydatków na żywność i napoje bezalkoholowe, których udział w całości wydatków zmniejszył się z 26,9\% (2006 r.) do 24\% (2015 r.), czyli o 2,9 p.p. W przypadku wydatków na utrzymanie mieszkania lub domu oraz nośniki energii w badanym okresie odnotowano niewielki wzrost ich udziału w całości wydatków gospodarstw domowych z 19,7\% do 20,1\%. Oznacza to, że przeciętne polskie gospodarstwo domowe nadal (tak jak w 2006 r.) przeznacza ok. 1/5 swoich wydatków na utrzymanie mieszkania (lub domu) i nośniki energii (rys. 1). 


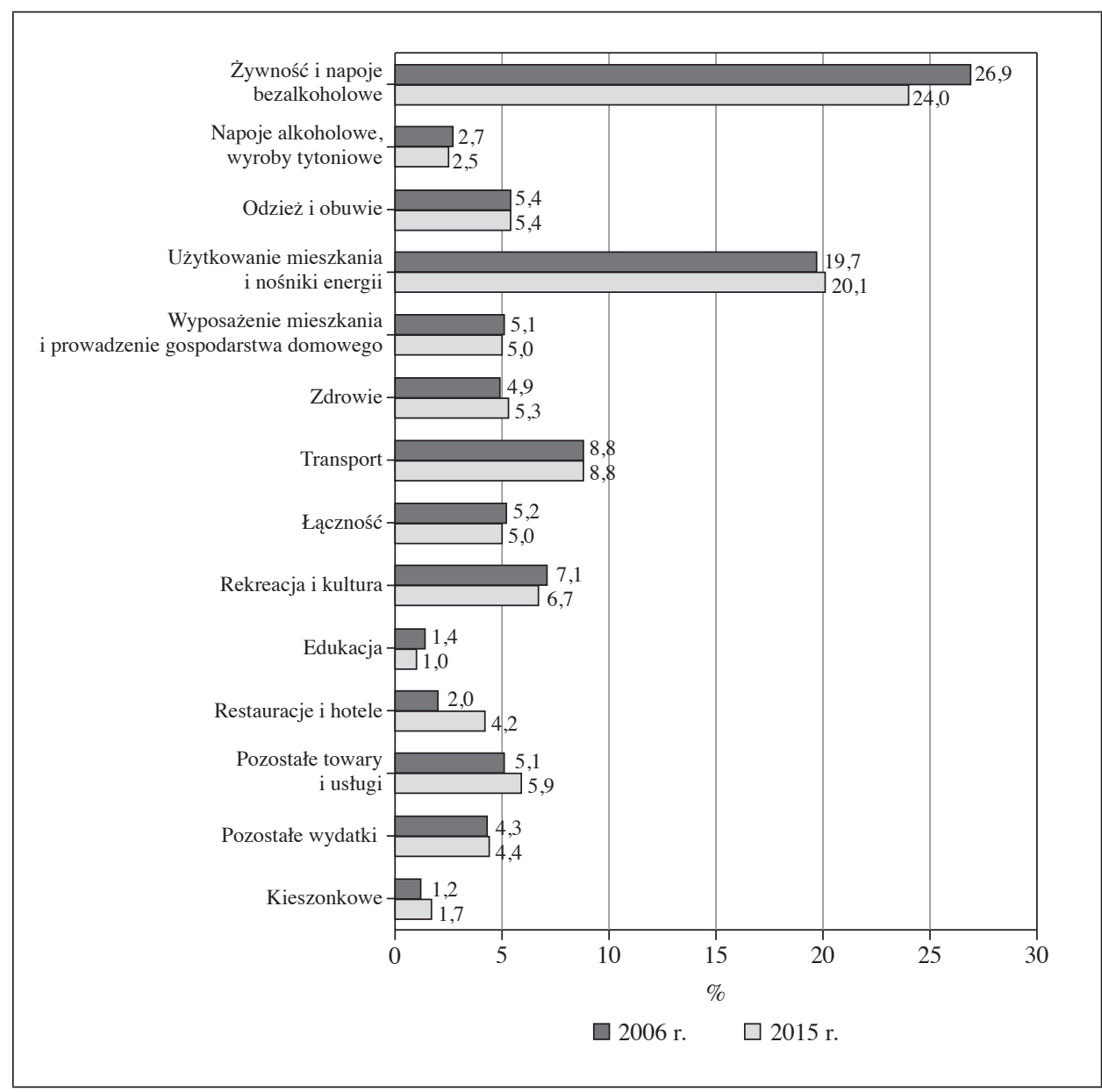

Rys. 1. Struktura przeciętnych miesięcznych wydatków na jedną osobę w gospodarstwie domowym (w \% wydatków ogółem) w latach 2006-2015

Źródło: (Badania budżetów... 2007, s. 60, Badania budżetów... 2016, s. 47).

Ponadto w analizowanym okresie największe zmiany (spadki) w strukturze wydatków gospodarstw domowych dotyczą takich kategorii wydatków, jak: edukacja (spadek o 0,4 p.p.), rekreacja i kultura (0,4 p.p.), napoje alkoholowe i wyroby tytoniowe $(0,2$ p.p.), łączność $(0,2$ p.p.) oraz wyposażenie mieszkania i prowadzenie gospodarstwa domowego ( 0,1 p.p.). Gospodarstwa domowe wydają natomiast więcej na restauracje i hotele (wzrost o 2,2 p.p), kieszonkowe (0,5 p.p.), użytkowanie mieszkania i nośniki energii ( 0,4 p.p.) oraz zdrowie $(0,3$ p.p). Analizowane zmiany mogą świadczyć o poprawie standardu życia polskich gospodarstw 
domowych, na co wskazują szczególnie dane o obniżeniu udziału wydatków na żywność i napoje bezalkoholowe w wydatkach ogółem, jak i wzrost udziału wydatków na restauracje i hotele, które to wydatki można traktować jako dobra wyższego rzędu. Nadal jednak prawie połowa (44,1\% w 2015 r.) wydatków gospodarstw domowych to wydatki na dobra pierwszej potrzeby, takie jak żywność i napoje bezalkoholowe oraz użytkowanie mieszkania lub domu i nośniki energii, które to wydatki łącznie obniżyły się w stosunku do 2006 r. o 2,5 p.p. Warto jednak podkreślić, że w latach 2006-2015 następowała systematyczna poprawa wyposażenia gospodarstw domowych w dobra trwałego użytkowania nowej generacji, takie jak: telewizor plazmowy lub ciekłokrystaliczny z MPEG-4, smartfon, komputer z szerokopasmowym dostępem do internetu, zmywarka do naczyń, kuchenka mikrofalowa czy robot kuchenny. Polepszeniu uległy również warunki mieszkaniowe, co dotyczy zwłaszcza wielkości użytkowanych mieszkań (Badania budżetów... 2016).

Zaobserwowany wzrost wydatków gospodarstw domowych oraz zmiany ich struktury mogły być konsekwencją nie tylko wzrostu dochodów rozporządzalnych, ale także zmian wartości aktywów finansowych gospodarstw domowych. Jak wynika z analizy rys. 2, w badanym okresie po początkowych spadkach spowodowanych najprawdopodobniej skutkami światowego kryzysu finansowego wartość aktywów netto polskich gospodarstw domowych stopniowo rosła.

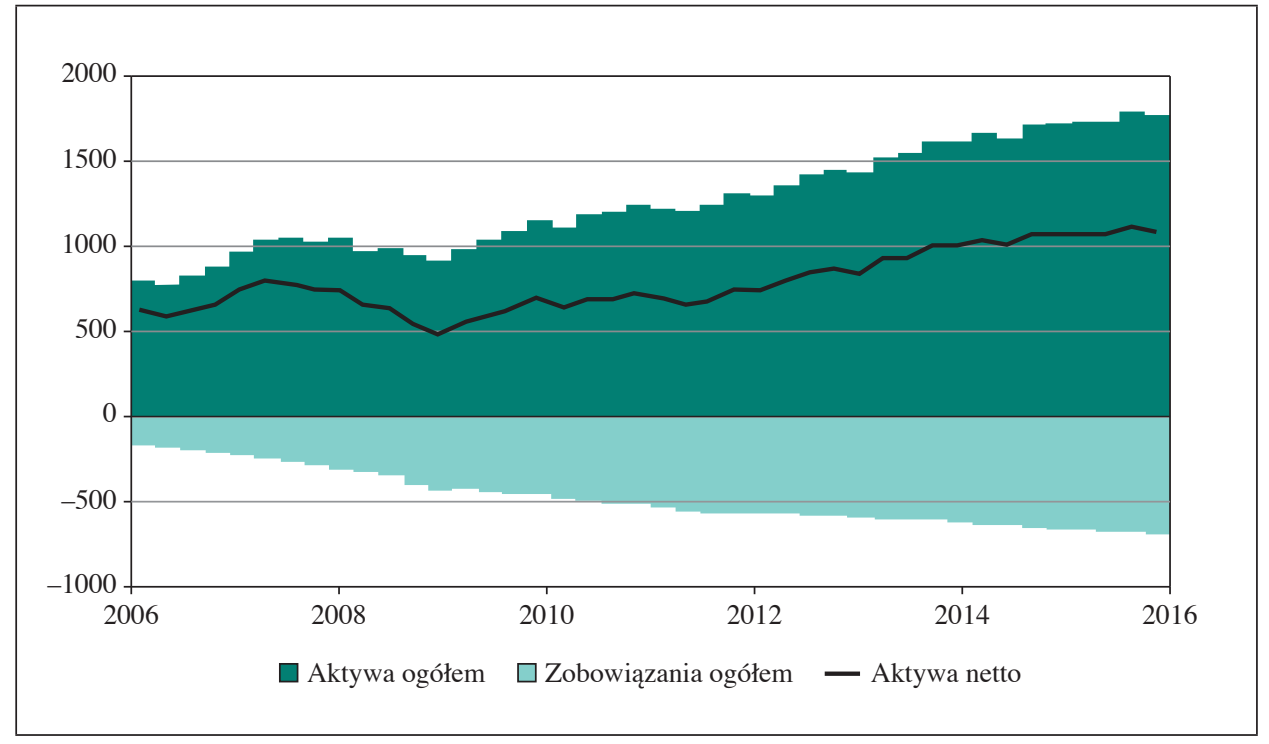

Rys. 2. Aktywa i zobowiązania finansowe gospodarstw domowych (w mld zł) Źródło: (Sytuacja finansowa sektora gospodarstw domowych w II kw.... 2016, s. 15). 
Co istotne, w badanym okresie wzrostowi wartości aktywów finansowych gospodarstw domowych towarzyszyło zwiększanie się ogólnej wielkości ich zobowiązań finansowych. Część z tych zobowiązań gospodarstwa domowe przeznaczały na zakupy dóbr i usług konsumpcyjnych. Według danych NBP tzw. spożycie prywatne ${ }^{11}$, szczególnie w ostatnim okresie, było jednak tylko w niewielkim stopniu finansowane kredytem. Od początku 2013 r. przyrost kredytu stanowił ok. $1 \%$ wartości tego spożycia (średnią z okresu boomu kredytowego w latach 2007-2008 szacowano na 3,5\%) (Sytuacja finansowa... 2016, s. 10).

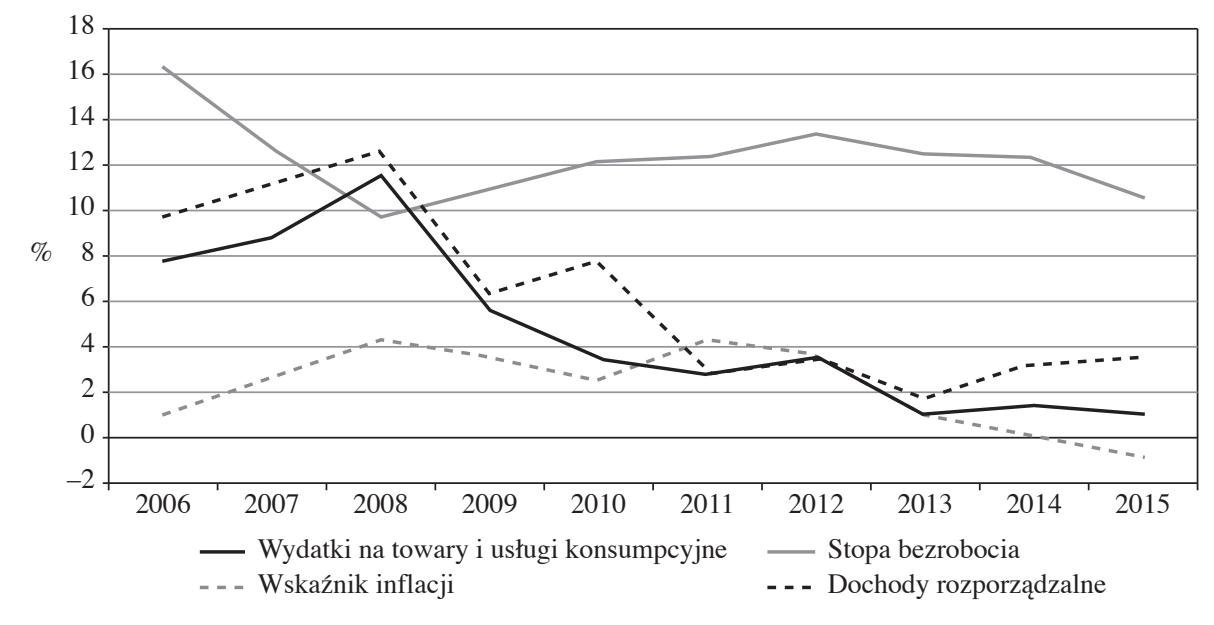

Rys. 3. Dochód rozporządzalny, wydatki na towary i usługi konsumpcyjne, stopa bezrobocia, wskaźnik cen dóbr i usług konsumpcyjnych (średnioroczne zmiany w \%) w latach 2006-2015

Źródło: opracowanie własne na podstawie (Badania budżetów... 2016).

Analiza zachowań w sferze konsumpcji polskich gospodarstw domowych w całym badanym okresie - wykazuje istotną dodatnią zależność między tempem zmian ich dochodów rozporządzalnych a stopą wzrostu wydatków na towary i usługi konsumpcyjne. Odwrotna korelacja występuje pomiędzy wydatkami a stopą bezrobocia, co oznacza, że gospodarstwa domowe silnie reagują na informacje płynące z rynku pracy. Zła sytuacja na rynku pracy, niepewność co do

${ }^{11}$ Spożycie prywatne - wydatki gospodarstw domowych na różnorodne dobra i usługi, m.in. rynkowe i nierynkowe (np. edukacja, ochrona zdrowia, sport, turystyka), użytkowanie mieszkania, a także spożycie naturalne produktów rolnych pochodzących z własnej produkcji (nie obejmuje ono takich pozycji, jak: zakupy ziemi, mieszkań czy domów) (Informacja GUS... 2016). 
możliwości utrzymania pracy czy jej znalezienia skutkują większą wstrzemięźliwością gospodarstw domowych w kwestii zakupów. Jak wynika z analizy rys. 3, konsumenci mocno reagują na kryzys w gospodarce krajowej stanowiący efekt złej koniunktury na rynku międzynarodowym, na co wskazuje zbieżność spadku stopy wzrostu wydatków konsumpcyjnych z rozprzestrzenianiem się międzynarodowego kryzysu finansowego (który rozpoczął się w połowie 2007 r.). W przypadku stopy inflacji w okresie badania nie można wykazać jednoznacznej zależności między tym wskaźnikiem a tempem zmian wydatków na towary i usługi konsumpcyjne gospodarstw domowych. Przez dużą część badanego okresu zmiany te, wbrew oczekiwaniom, zachodziły w tym samym kierunku, czyli wzrostowi cen towarzyszyło podniesienie stopy wzrostu wydatków konsumpcyjnych. Tendencja wskazuje, że gospodarstwa domowe w swych zachowaniach na rynku dóbr i usług większą wagę przywiązują do oczekiwanych zmian cen niż ich aktualnego poziomu. Z drugiej strony mimo ograniczania konsumpcji gospodarstwa domowe mogą wydawać więcej przy niezmienionej lub obniżonej konsumpcji z powodu wyższych cen na rynku dóbr i usług konsumpcyjnych.

To, jak zachowują się gospodarstwa domowe w sferze konsumpcji, w dużej mierze zależy więc od bieżącej koniunktury gospodarczej, która determinuje również koniunkturę gospodarstw domowych. Rys. 4 przedstawia wyniki badań koniunktury konsumenckiej ${ }^{12}$, które pokazują, jak zmieniała się percepcja sytuacji ekonomiczno-finansowej gospodarstw domowych.

Jak wynika z analizy rys. 4, po początkowej poprawie koniunktury w latach 2006 i 2007, od 2008 r. - najprawdopodobniej w wyniku globalnego kryzysu finansowego - odnotowywano jej stopniowe pogorszanie się trwające do $2012 \mathrm{r}$. W 2013 r. nastąpiło odwrócenie tego negatywnego trendu spowodowane zarówno lepszą oceną ogólnej sytuacji w kraju (obecnej i przyszłej), jak i korzystniejszym postrzeganiem własnej (obecnej i przyszłej) sytuacji finansowej. Poprawiły się również nastroje, jeśli chodzi o dokonywanie ważniejszych zakupów.

W przypadku oczekiwań konsumentów co do najbliższej przyszłości zaobserwowano większe wahania tendencji konsumpcji (wyprzedzającego wskaźnika ufności konsumenckiej - WWUK) w stosunku do tendencji bieżących (zmiany bieżącego wskaźnika ufności konsumenckiej - BWUK). WWUK, tak jak BWUK, rósł przez pierwsze dwa lata badanego okresu (2006 i 2007), po czym nastąpił jego spadek, który trwał jednak krócej, gdyż do 2009 r. W 2010 r. nastąpiła krótkotrwała poprawa nastrojów konsumenckich - wzrost WWUK. Lata 2011 i 2012 to spadek koniunktury spowodowany przede wszystkim pogorszeniem się sytuacji na

$12 \mathrm{~W}$ badaniach uwzględnia się subiektywne oceny przedstawicieli gospodarstw domowych dotyczące bieżącej i przyszłej sytuacji finansowej własnego gospodarstwa domowego, bieżącej i przyszłej sytuacji ekonomicznej kraju, zmian cen, poziomu bezrobocia, warunków zakupowych czy oszczędzania pieniędzy. 


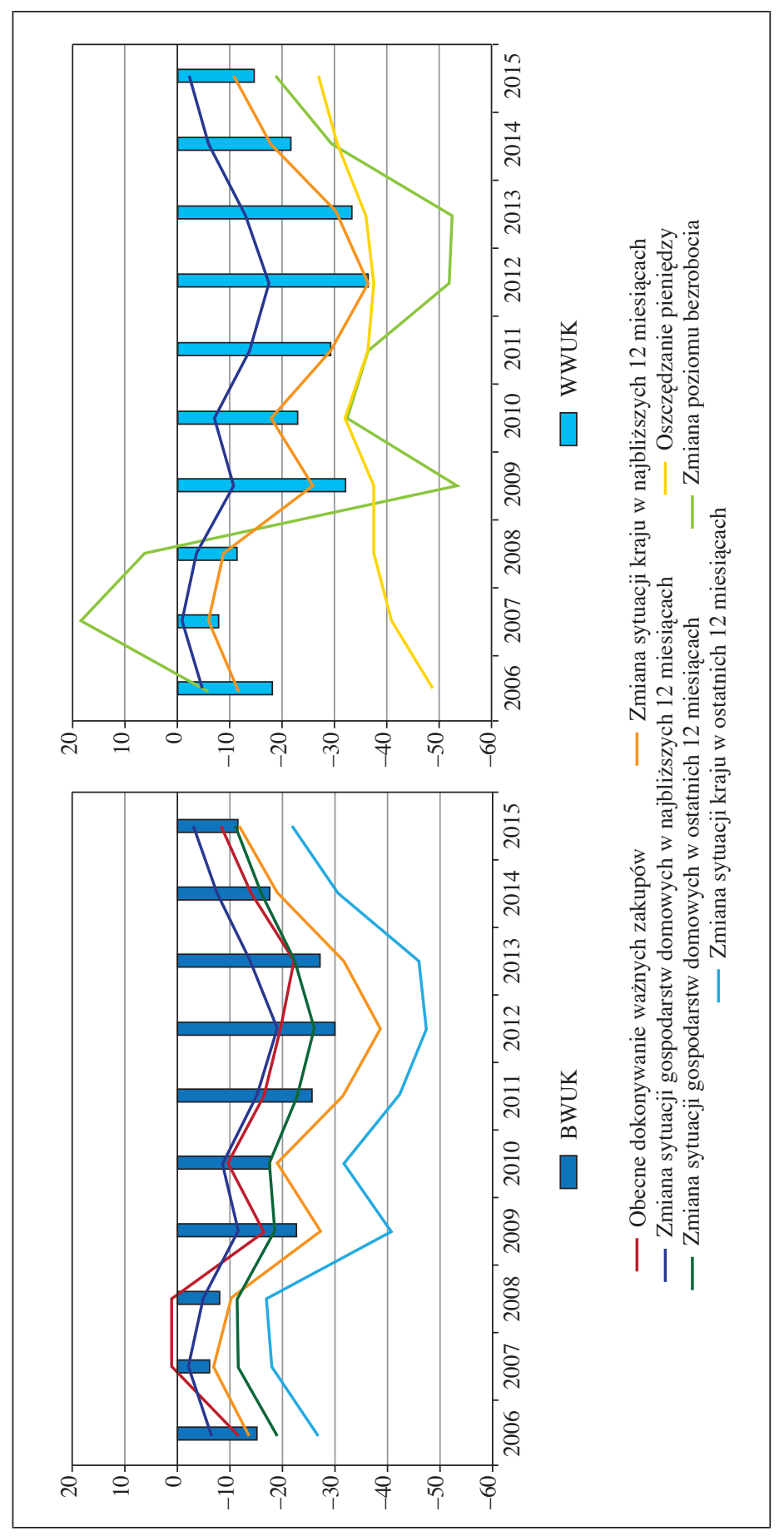

密

育芯敦

造

馬

के

घ)

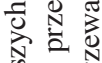

กิ $\frac{\mathrm{N}}{\mathrm{L}}$

盯 苛

3 . 총

焉焉

응

㣢识

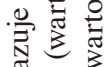

응 흉을

ำ

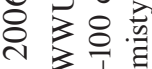

过

ब

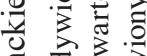

可记

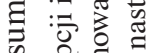

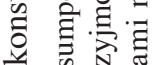

금츄

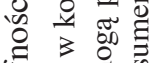

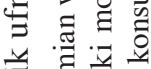

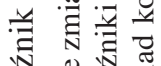

氖

ते एँ

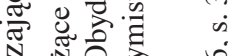

式

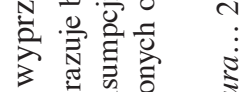

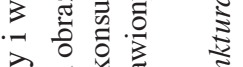

강

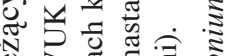

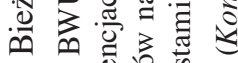

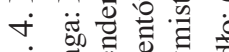

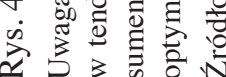


rynku pracy oraz sytuacji gospodarczej w kraju. W 2013 r. odnotowano poprawę koniunktury, która to tendencja utrzymała się do 2015 r.; poprawie WWUK towarzyszyła również coraz lepsza sytuacja na rynku pracy.

Rys. 5 przedstawia związek między dochodami do dyspozycji, spożyciem prywatnym, sprzedażą detaliczną a ufnością konsumencką.

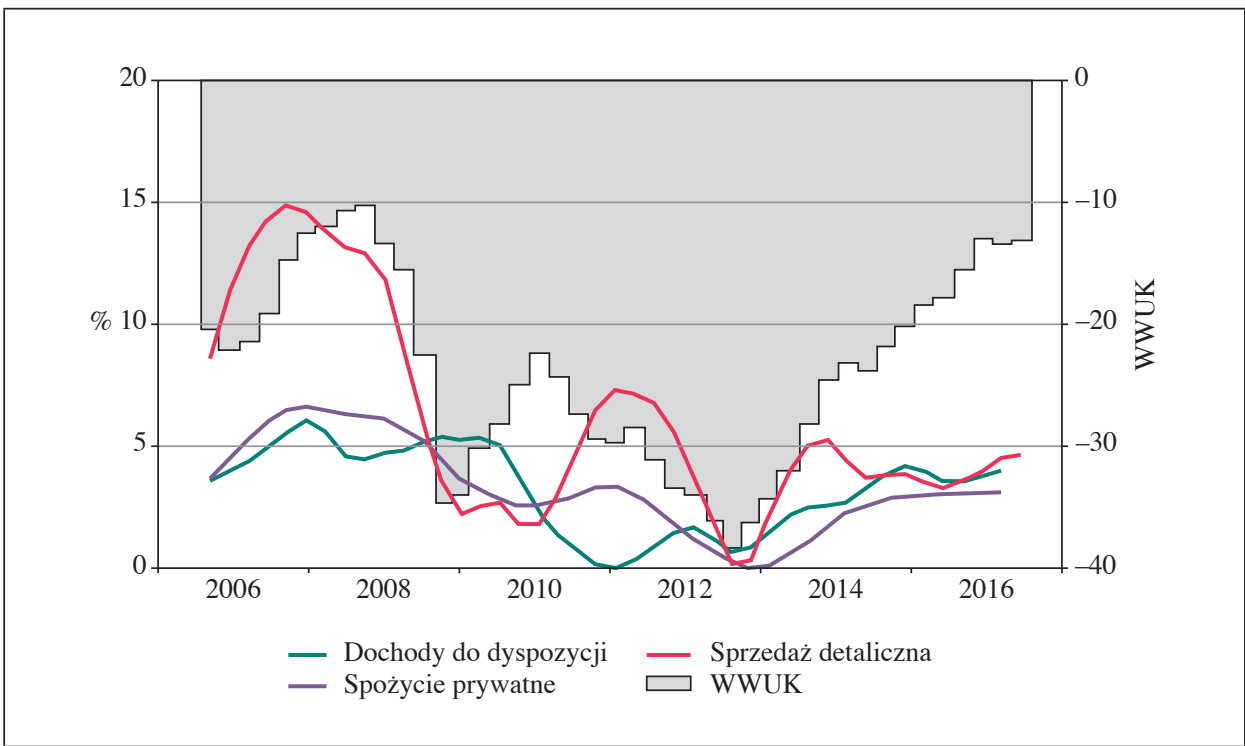

Rys. 5. Dochody do dyspozycji, spożycie prywatne, sprzedaż detaliczna i WWUK w latach 2006-2016

Uwaga: dochody do dyspozycji - dochód rozporządzalny pomniejszony o pozostałe wydatki; jest on przeznaczony na wydatki na towary i usługi konsumpcyjne oraz przyrost oszczędności. Sprzedaż detaliczna to częściowo konsumpcja gospodarstw domowych, a częściowo detaliczne zakupy firm czy innych podmiotów. Oblicza się ją jako sprzedaż towarów własnych i komisowych (nowych i używanych) w punktach sprzedaży detalicznej (nie uwzględnia np. zakupów usług przez gospodarstwa domowe).

Źródło: (Sytuacja finansowa sektora gospodarstw domowych w II kw. ... 2016, s. 9).

Jak wynika z badań NBP, zależność dynamiki spożycia prywatnego (jak również sprzedaży detalicznej) charakteryzuje się dużą zmiennością w czasie. Porównując te badania z badaniami koniunktury konsumenckiej, można stwierdzić, że w ostatnich latach dynamika spożycia prywatnego była niższa od dynamiki sprzedaży detalicznej i pozostawała w silnym związku z koniunkturą konsumencką. Występowało to jednak z pewnym przesunięciem czasowym. W $2015 \mathrm{r}$. - mimo że następowała znaczna systematyczna poprawa koniunktury konsumenckiej, o czym świadczą zmiany wskaźnika WWUK - w warunkach relatywnie 
wysokiej dynamiki dochodów do dyspozycji gospodarstwa domowe w relatywnie niskim stopniu zwiększały swoją konsumpcję (Sytuacja finansowa sektora gospodarstw domowych w II kw. ... 2016, s. 9). Mogła to być konsekwencja obaw konsumentów związanych z niestabilną sytuacją na rynku międzynarodowym, jak i sytuacją polityczną i gospodarczą w kraju.

\section{Zakończenie}

Od 2006 r. sytuacja materialna polskich gospodarstw domowych stopniowo się poprawia. Świadczy o tym zarówno systematyczny wzrost ich dochodów rozporządzalnych, jak i zwiększenie wartości posiadanych przez nie aktywów finansowych. Gospodarstwa domowe wydają obecnie więcej w wartościach bezwzględnych, mimo że udział wydatków w dochodzie rozporządzalnym konsekwentnie spada. Oznacza to, że mogą one zwiększać swoje oszczędności, a tym samym przyszłą konsumpcję. O wpływie coraz lepszej sytuacji ekonomicznej polskich gospodarstw domowych na ich konsumpcję świadczy również coraz lepsze wyposażenie mieszkań i domów w dobra tzw. wysokiej technologii. Poprawa sytuacji bytowej polskich gospodarstw domowych przejawia się również w polepszeniu ich warunków mieszkaniowych, co dotyczy zwłaszcza wielkości użytkowanych przez nie mieszkań. Zmienia się również struktura ich konsumpcji. Polskie gospodarstwa domowe większą część swoich budżetów przeznaczają obecnie na dobra wyższego rzędu, np. restauracje i hotele, ograniczeniu uległy natomiast wydatki na dobra podstawowe, takie jak żywność i napoje bezalkoholowe, mimo że te ostatnie stanowią nadal znaczną część ich wydatków.

Podejmując swoje decyzje konsumpcyjne, gospodarstwa nie kierują się jednak wyłącznie swoją bieżącą sytuacją ekonomiczno-finansową. Dużą rolę odgrywa również bieżąca sytuacja gospodarcza kraju. Warto zaznaczyć, że w przypadku polskich gospodarstw domowych w analizowanym okresie można zaobserwować wyraźny spadek konsumpcji spowodowany międzynarodowym kryzysem finansowym. Jest to widoczne szczególnie w latach 2008-2012, kiedy to słabnącym wskaźnikom makroekonomicznym towarzyszyło również pogarszanie się nastrojów konsumenckich, a w konsekwencji spadek zakupów dóbr i usług, a tym samym konsumpcji. Jak wynika z badań, na decyzje gospodarstw domowych w zakresie wydatków na towary i usługi konsumpcyjne największy wpływ ma sytuacja na rynku pracy. Łatwość znalezienia pracy czy pewność dotycząca utrzymania bieżącego zatrudnienia w dużej mierze determinują decyzje gospodarstw domowych w zakresie konsumpcji. 


\section{Literatura}

Badania budżetów gospodarstw domowych w 2006 r. (2007), GUS, Warszawa.

Badania budżetów gospodarstw domowych w 2015 r. (2016), GUS, Warszawa.

Bauman Z. (2000), Globalizacja, PIW, Warszawa.

Becker G.S. (1990), Ekonomiczna teoria zachowań ludzkich, PWN, Warszawa.

Bohlen B., Carlotti S., Mihas L. (2010), How the Recession Has Changed US Consumer Behavior, „McKinsey Quarterly”, vol. 1.

Bywalec C. (2010), Konsumpcja a rozwój gospodarczy i społeczny, Wydawnictwo C.H. Beck, Warszawa.

Bywalec C. (2012), Ekonomika i finanse gospodarstw domowych, PWE, Warszawa.

Bywalec C., Rudnicki L. (2002), Konsumpcja, PWE, Warszawa.

Deaton A.S. (1974), Reconsideration of the Empirical Implications of Additive Preferences, „Economic Journal”, vol. 84, nr 334, https://doi.org/10.2307/2231258.

Desvaux G., Regaout B., Labaye B., Yu F., Mednonca L. (2009), Beating the Recession: Buying into New European Consumer Strategies, McKinsey Global Institute.

Douglas M., Isherwood B. (1996), The World of Goods, Routledge, London.

Drabik I. (2011), Tendencje zmian zachowań konsumentów na rynku globalnym, Lviv Polytechnic National University Institutional Repository, http://ena.lp.edu.ua (data dostępu: 12.07.2016).

Graham J. (2010), Critical Thinking in Consumer Behavior: Cases and Experiential Exercises, Prentice Hall, New Jersey.

Grotowska-Leder J. (2011), Zaradny, czy bezradny? Strategie życiowe współczesnych Polaków w świetle wybranych wyników badań ogólnopolskich, ,Zeszyty Naukowe PTE", nr 9.

Hermann S. (2009), The Crisis and Consumer Behavior: Eight Quick Solutions, ,Journal of Consumer Behavior", vol. 8.

Hodoly A. (1971), Gospodarstwo domowe i jego rola społeczno-ekonomiczna, KiW, Warszawa.

Informacja GUS o metodologii szacunków kwartalnych produktu krajowego brutto, http:// stat.gov.pl/cps/rde/xbcr/gus/informacja_metedologia_szac_kw_pkb.pdf (data dostępu: 15.11.2016).

Koniunktura konsumencka. Lipiec 2016 r. (2016), GUS, Warszawa, http://stat.gov.pl/ obszary-tematyczne/koniunktura/koniunktura/koniunktura-konsumencka-lipiec-2016-roku,1,41.html (data dostępu: 15.08.2016).

Luszniewicz A. (1972), Statystyka poziomu życia ludności, PWE, Warszawa.

Nowak J. (2012), Social media jako sieci obiegu przekazów medialnych, „Nowe Media”, nr 3.

Palska H. (2000), Styl życia. Stan badań i nowe potrzeby badawcze (w:) Homo eligens, Księga Jubileuszowa prof. Andrzeja Sicińskiego, IFiS PAN, Warszawa.

Polityka makroekonomiczna $w$ warunkach kryzysu i jej pływ na gospodarke. Teoria i praktyka (2011), red. Z. Dach, Wolters Kluwer, Warszawa.

Rachocka J. (2003), Dekonsumpcja, domocentryzm, ekologizacja życia - nowe tendencje konsumenckie w rozwiniętych gospodarkach rynkowych (w:) Problemy globalizacji gospodarki, red. T. Bernat, PTE, Szczecin.

Sytuacja finansowa sektora gospodarstw domowych w IV kw. 2015 r. (2016), nr 02/16 (lipiec 2016 r.), Instytut Ekonomiczny NBP, Warszawa. 
Sytuacja finansowa sektora gospodarstw domowych w II kw. 2016 r. (2016), nr 04/16 (listopad 2016 r.), Instytut Ekonomiczny NBP, Warszawa.

Szczepański J. (1981), Konsumpcja a rozwój człowieka. Wstęp do antropologicznej teorii konsumpcji, PWE, Warszawa.

Zalega T. (2008a), Konsumpcja w gospodarstwach domowych o niepewnych dochodach a teorie konsumpcji, ,Ekonomista”, nr 6.

Zalega T. (2008b), Konsumpcja w gospodarstwach domowych o niepewnych dochodach, Wydawnictwo Naukowe Uniwersytetu Warszawskiego, Warszawa.

Zalega T. (2011), Wpływ kryzysu na postawy i zachowania gospodarstw domowych wysokodochodowych, ,Nierówności Społeczne a Wzrost Gospodarczy”, nr 18.

Zalega T. (2013), Wpływ kryzysu na konsumpcję i zachowania konsumpcyjne gospodarstw domowych, „Problemy Zarządzania”, nr 1.

\section{The Economic Conditions of Household Consumption Behaviour in Poland in the Years 2006-2015}

(Abstract)

The objective of this study is to determine factors of consumer behaviour with a particular emphasis on economic ones. Taking into account the characteristic conditions in which modern households operate, an attempt is made to identify those factors that operate not only on micro and/or macroeconomic scales, but also on a global scale. The study analyses the determinants of consumer behaviour in Polish households from 2006 - at which point they began to gradually feel the effects of accession to the European Union. Preliminary results indicate that changes in consumption across Polish households were influenced not only by changes in those homes' financial situation, in the form of increased income or asset value, but also in the current and expected economic situation in Poland as well as the rest of the world.

Keywords: household, consumption, globalisation, consumer sentiment. 